\title{
Body shape variation of Garra rufa (Heckel) (Teleostei: Cyprinidae) using geometric and morphometric techniques
}

\author{
Mazaher Zamani-Faradonbe ${ }^{1 *}$, Yazdan Keivany ${ }^{1}$, Salar Dorafshan ${ }^{1}$, Mojtaba Abbasi- \\ Jeshvaghani $^{2}$ \\ ${ }^{1}$ Department of Natural Resources (Fisheries Division), Isfahan University of Technology, Isfahan, 84156- \\ 83111, Iran \\ ${ }^{2}$ Department of Animal Science, College of Agriculture, Isfahan University of Technology, Isfahan, 84156- \\ 83111, Iran \\ "Correspondingauthor四:mazaher.zamani@na.iut.ac.ir;m.zamanif68@gmail.com
}

Received: 11 March 2020

Accepted: 17 May 2020

Published online: 25 May 2020

\begin{abstract}
Organisms can adapt to habitat conditions that ensure their survival. Habitat separation can lead to different populations of body shape during the phenotypic plasticity process. Both traditional and geometric morphology are being used in fish population studies. In this study, the body shape differences between Garra rufa (Heckel) populations captured in the Jarrahi River (from the Tigris Basin) were investigated using traditional and geometric morphometric methods. The samples were captured from the Rostam Abad, Aghajari and Behbahan tributaries and transferred to the laboratory. For the traditional morphometric analysis, 10 meristic characters and 19 morphometric characters were measured. Geometric morphological information was extracted using 13 landmark points on left side photographs of individual fish. According to the results of the traditional morphometric analysis, there were differences between the three populations in meristic (lateral line scales, predorsal scales, circamucaudal scales) and morphometric (14 of 19 characters) traits. In the geometric morphometric analysis, the major part of the shape variation is due to landmark points in the head region and the dorsal fin base, with the anal fin and caudal peduncle being the most conservative body regions. The populations had significant differences in body shape with populations from Aghajari and Behbahan tributaries being most similar and the Rostam Abad population was different from the two other populations.
\end{abstract}

Key words: Geometric, plasticity, habitat, biology, ecology, phenotype

\section{Introduction}

Organisms can adapt to environmental conditions that ensure their survival. During the anatomical development history and ontogeny of each organism, the formation of its body shape is strongly influenced by the environmental conditions, and fish, like other organisms can show a similar ability (Nacua et al., 2010). Fish experience different environmental conditions throughout their life that can affect various traits including their body shape (Costa and Cataudella, 2007). 
The study of the phenotypic plasticity in populations that live in different environmental conditions allows us to better understand changes in population characteristics in relation to environmental changes (Kuliev, 1988). Habitat separation can lead to the formation of different populations of fish species during the phenotypic plasticity process, due to various environmental factors (Wootton, 1990). Morphological characteristics of fish are very sensitive to environmental factors such as substrate type, water flow, vegetation, competition, predation and availability of food sources (Nicieza, 1995).

Traditional morphometric approaches like morphometric and meristic characteristics and geometric morphometric approaches like landmark-based and truss network have a widespread application in fish population investigations, systematics, and separation of fish populations (Bakhoum, 1994). These features are used as an effective way to identify differentiation and overlap in populations and are the first step in assessing the population structure of any species (Turan, 1999).

The genus Garra Hamilton belongs to the carp family (Cyprinidae) and has at least 100 species world-wide (Fricke et al., 2019) and 11 species in Iran (Esmaeili et al., 2018; Mousavi-Sabet et al., 2019). The species, Garra rufa (Heckel), is a small-sized, tropical and widespread freshwater fish that lives in Syria, Iran, Iraq and Turkey (Fricke et al., 2019). Previous studies on G. rufa are limited and focused on length-weight and length-length relationships (Esmaeili and Ebrahimi, 2006; Gerami et al., 2013; Hamidan and Britton, 2013; Hashemzadeh Segherloo et al., 2015; Keivany et al., 2015b; Keivany and Zamani-Faradonbe, 2017), karyotype (Gorshkova et al., 2012), microbiological risks to humans (Heistinger et al., 2011), reproductive biology and age determination (Abedi et al., 2011), and mortality (Majtán et al., 2012). Some of them also used morphological and morphometric characters to separate G. rufa populations (Keivany et al., 2015a; Cicek et al., 2016; Yedier et al., 2016).

The aim of this study is to investigate the body shape diversity in Garra rufa population(s) in the Jarrahi River using two methods, geometric morphometric and traditional morphometric methods.

\section{Material and Methods}

For this study, 55 specimens of Garra rufa were collected using electrofishing techniques during October 2017 from three different populations (19 specimens from Rostam Abad, 22 specimens from Aghajari and 14 specimens from Behbahan tributaries) from the Jarrahi River (Fig. 1). The ecological parameters of these sites are in Table 1. Captured fish, after anesthesia with a standard solution (1\%) of Clove oil, were preserved in $10 \%$ neutralized formalin solution and transferred to the laboratory for analysis.

\section{Traditional Morphometric Analysis}

Ten meristic characters including the number of soft rays in the dorsal, caudal, anal, ventral and pectoral fins, the number of scales on the lateral line, above the lateral line, below the lateral line (to pelvic-fin origin and anal fin origin), circamucaudal and predorsal were counted. Also, 19 morphometric characters (Fig. 2) were measured with a digital caliper $(0.1$ $\mathrm{mm}$ accuracy). The methods for ray and scale counts and measurements follow Kottelat and Freyhof (2007).

The three measurements in the head area, including the snout length, the eye diameter, and the postorbital length, were modified by dividing by head length and the other measurements, excluding the total, fork and standard length were modified by dividing by standard length. Therefore, total length, fork length and standard length were used in the analysis without 
modification. After modification of the above-mentioned data, all the meristic and morphometric characters were analyzed for normality distribution using the KolmogorovSmirnov test. Nonparametric data were analyzed using the Kruskal-Wallis test and parametric data were analyzed using the ANOVA test in SPSS software version 19.

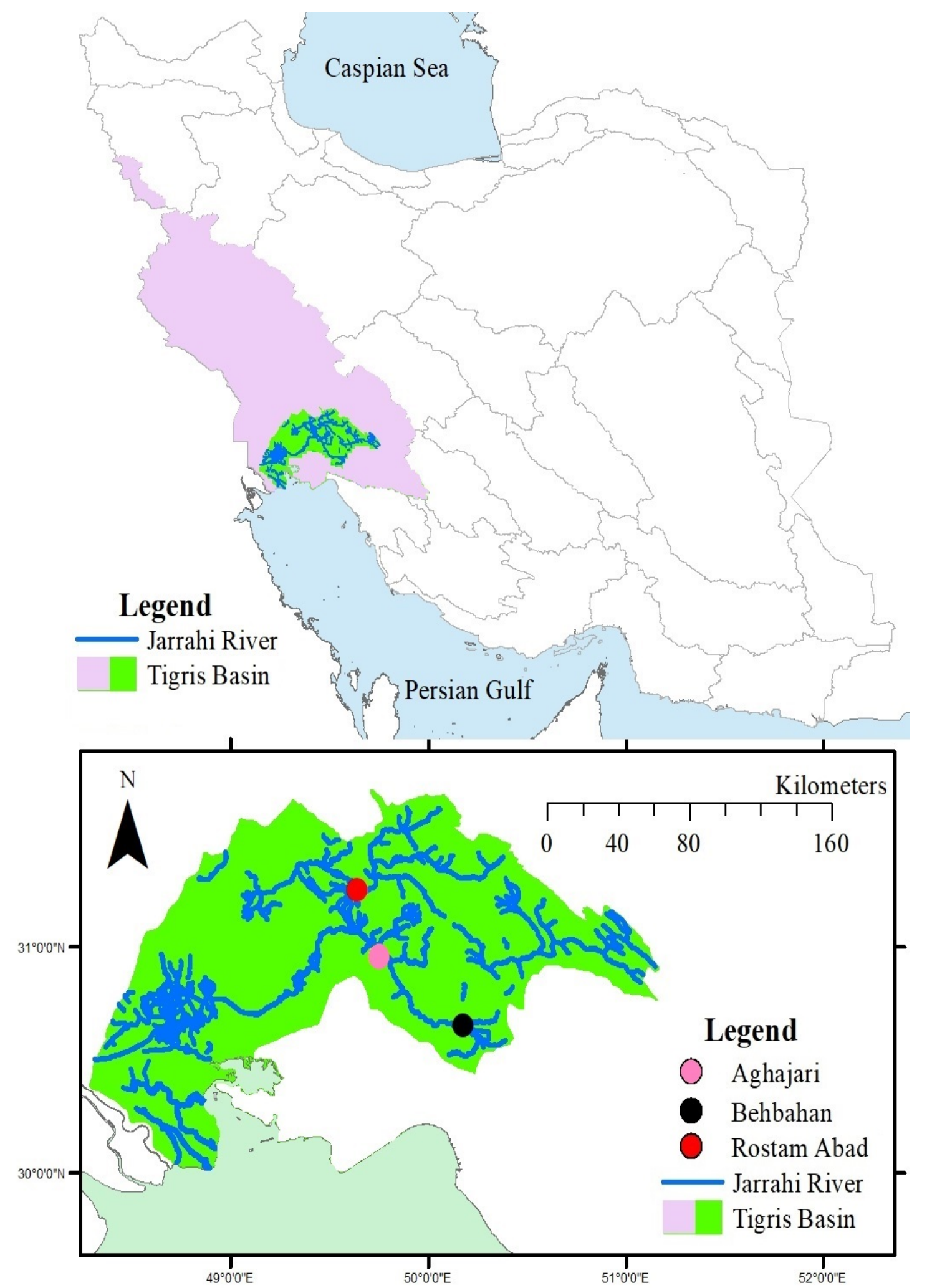

Figure 1: Location of the study area in Khuzestan Province and Iran. Map created in ArcGIS (version 10.3) with Imagery Basemap. 
Table 1: Description of some ecological parameters of the sampled sites in this study.

\begin{tabular}{lccccccc}
\hline \multicolumn{1}{c}{ Population } & No. & Temperature & EC & TDS & pH & Habitat & Current \\
\hline Rostam Abad & 19 & 25.3 & 3646 & 1825 & 8.40 & River & Moderate \\
Aghajari & 22 & 24.5 & 2582 & 1291 & 8.46 & Large river & Fast \\
Behbahan & 14 & 25.8 & 2484 & 1242 & 7.93 & River & Moderate \\
\hline
\end{tabular}

No. $=$ Number of fish sampled; EC = Electrical conductivity; TDS = Total dissolved solids.

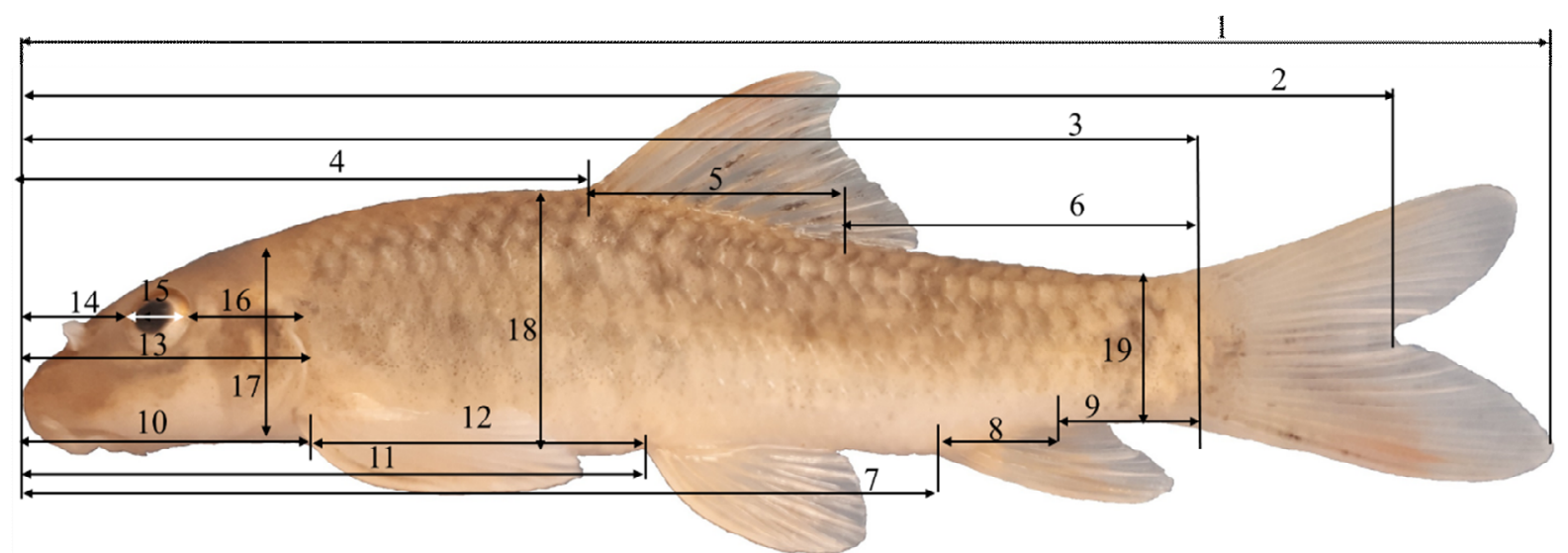

Figure 2: The localities of measurements on the left side of Garra rufa from the Jarrahi River. 1: Total length, 2: Fork length, 3: Standard length, 4: Predorsal fin length, 5: Dorsal fin base length, 6: Post-dorsal fin length, 7: Preanal fin length, 8: Anal fin base length, 9: Postanal fin length, 10: Prepectoral fin length, 11: Prepelvic fin length, 12: Pectoral-pelvic distance length, 13: Head length, 14: Snout length, 15: Eye diameter, 16: Postorbital length, 17: Head depth, 18: Body height, 19: Caudal peduncle depth.

\section{Geometric Morphometric Analysis}

To extract geometric morphometric information, the left side of the sample fish was photographed with a Canon digital camera (model EOS 800D), then 13 landmark points (Fig. 3) were selected and digitized by the TpsDig2 software version 2.10 (Rohlf, 2010). Then, to remove non-shape variations (like location, orientation and scale) from the obtained landmark configurations, they were superimposed by GPA (General Procrustes Analysis) (Rohlf and Bookstein, 1990) using MorphoJ software version 1.06d (Klingenberg, 2011) and PAST software version 2.17b (Hammer et al., 2001). Finally, the Principle Component Analysis (PCA), Canonical Variate Analysis (CVA) and Cluster Analysis (CA) were also conducted using MorphoJ software version 1.06d and PAST software version 2.17b.

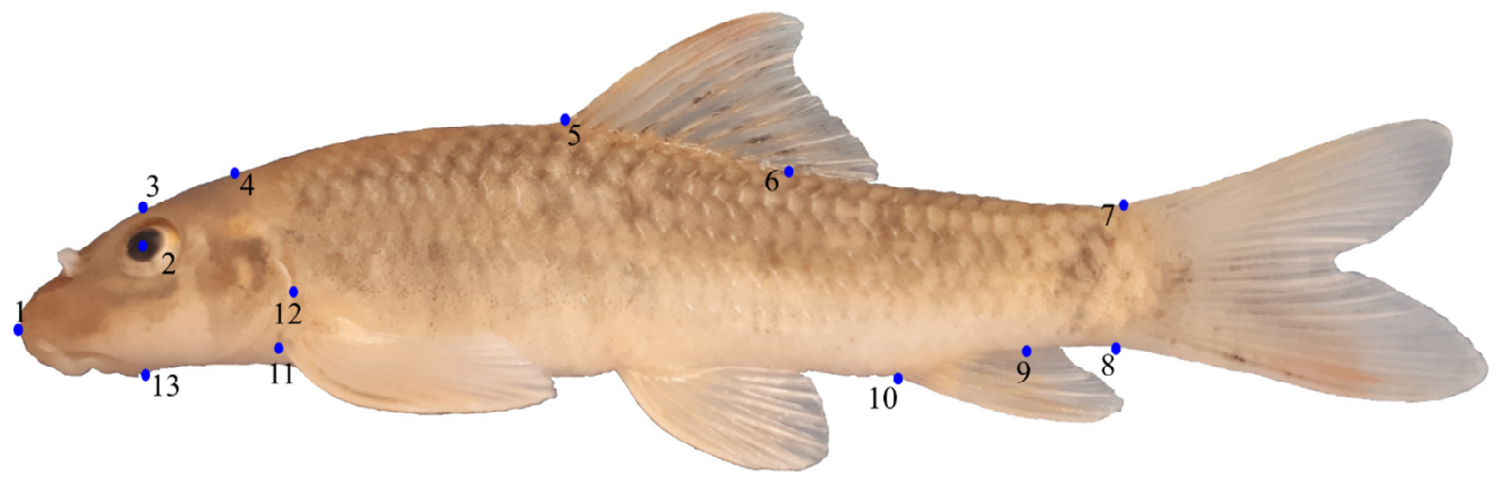

Figure 3: The localities of the 13 landmarks on left side of G. rufa specimens from the Jarrahi River. 


\section{Results}

\section{Traditional Morphometric Analysis}

Based on the Kolmogorov-Smirnov test, seven meristic characters were nonparametric and the results of Kruskal-Wallis analysis of these characters showed that there were no differences between the studied populations of G. rufa (Table 2) $(p>0.05)$. Four meristic characters were parametric and analysis by ANOVA test showed that the studied populations were different in three of them - the number of scales on the lateral line, the number of predorsal scales and the number of circamucaudal scales $(p<0.05)$ (Table 3$)$.

Based on the normality test, all modified and unmodified morphometric character data had normal distribution, so they were analyzed with the ANOVA test. The ANOVA test and Duncan grouping results are shown in Table 4 and populations were different in many characters $(p<0.05)$ except for the preanal fin length, anal fin base length, pectoral-pelvic distance length, head depth, and caudal peduncle depth $(p>0.05)$ (Table 4).

\section{Geometric Morphometric Analysis}

The PCA based on the landmark-based data shows that the first two principal components explained $56.21 \%$ of shape variation (Fig. 4): PC1 $=35.195 \%$, PC2 $=21.015 \%$. The populations are therefore partially grouped along the first two axes (PC1 and PC2) (Fig. 5). Morphological differences between the three populations sampled are visualized through thinplate spline transformation grids and photographic representations using principle axis values from the PCA. The major part of the shape variation is due to the landmarks of the head region (landmarks 1, 3, 5, 12 and 13) and the dorsal fin base (landmarks 5 and 6), with the anal fin and caudal peduncle being the most conservative body regions. Shape deformation along PC1 is mostly found on the head region and the beginning and end of the dorsal fin and shape deformation along PC2 is mostly found on the head region, the beginning and end of the dorsal fin and the beginning and end of the anal fin (Fig. 6).

Table 2: The Mean \pm SD and Kruskal-Wallis analysis results for nonparametric meristic characters in Garra rufa populations from the Jarrahi River $(p>0.05)$.

\begin{tabular}{|c|c|c|c|c|c|c|c|}
\hline Populations & $\begin{array}{l}\text { Above the } \\
\text { lateral line }\end{array}$ & $\begin{array}{l}\text { Below the } \\
\text { lateral line to } \\
\text { pectoral fin }\end{array}$ & $\begin{array}{l}\text { Below the } \\
\text { lateral line to } \\
\text { the anal fin }\end{array}$ & $\begin{array}{l}\text { Dorsal } \\
\text { fin rays }\end{array}$ & $\begin{array}{c}\text { Anal } \\
\text { fin rays }\end{array}$ & $\begin{array}{l}\text { Caudal } \\
\text { fin rays }\end{array}$ & $\begin{array}{c}\text { Ventral fin } \\
\text { rays }\end{array}$ \\
\hline Rostam Abad & $3.33 \pm .52$ & $3 \pm 0$ & $3 \pm 0$ & $8 \pm 0$ & $5 \pm 0$ & $17 \pm 0$ & $7.5 \pm .55$ \\
\hline Aghajari & $3.72 \pm .57$ & $3.28 \pm .46$ & $3.22 \pm .43$ & $8 \pm 0$ & $5 \pm 0$ & $16.86 \pm .35$ & $57.68 \pm .57$ \\
\hline Behbahan & $3 \pm 0$ & $3 \pm 0$ & $3 \pm 0$ & $8 \pm 0$ & $5 \pm 0$ & $17 \pm 0$ & $7.75 \pm .46$ \\
\hline$p$ & 0.149 & 0.155 & 0.216 & 1.00 & 1.00 & 0.347 & 0.345 \\
\hline
\end{tabular}

Table 3: Mean \pm SD and ANOVA analysis results for parametric meristic characters in Garra rufa populations from the Jarrahi River.

\begin{tabular}{ccccc}
\hline Populations & Lateral line scale & Pectoral $^{\text {n.s }}$ & Predorsal scales $^{\text {Circamucaudal scales }}$ \\
\hline Rostam Abad & $33.17 \pm 0.75^{\mathrm{b}}$ & $11.83 \pm 1.17$ & $11.5 \pm 0.55^{\mathrm{b}}$ & $14.67 \pm 1.21^{\mathrm{b}}$ \\
Aghajari & $33.28 \pm 0.96^{\mathrm{b}}$ & $11.91 \pm 0.81$ & $10.8 \pm 1.23^{\mathrm{b}}$ & $14.56 \pm 0.99^{\mathrm{b}}$ \\
Behbahan & $31.75 \pm 1.04^{\mathrm{a}}$ & $12.25 \pm 0.88$ & $9.12 \pm 0.35^{\mathrm{a}}$ & $13.75 \pm 1.19^{\mathrm{a}}$ \\
\hline${ }^{\mathrm{a}},{ }^{\mathrm{b}}:$ Duncan grouping in ANOVA $(p<0.05),{ }^{\text {n.s. }}$ : not significant $(p>0.05)$.
\end{tabular}




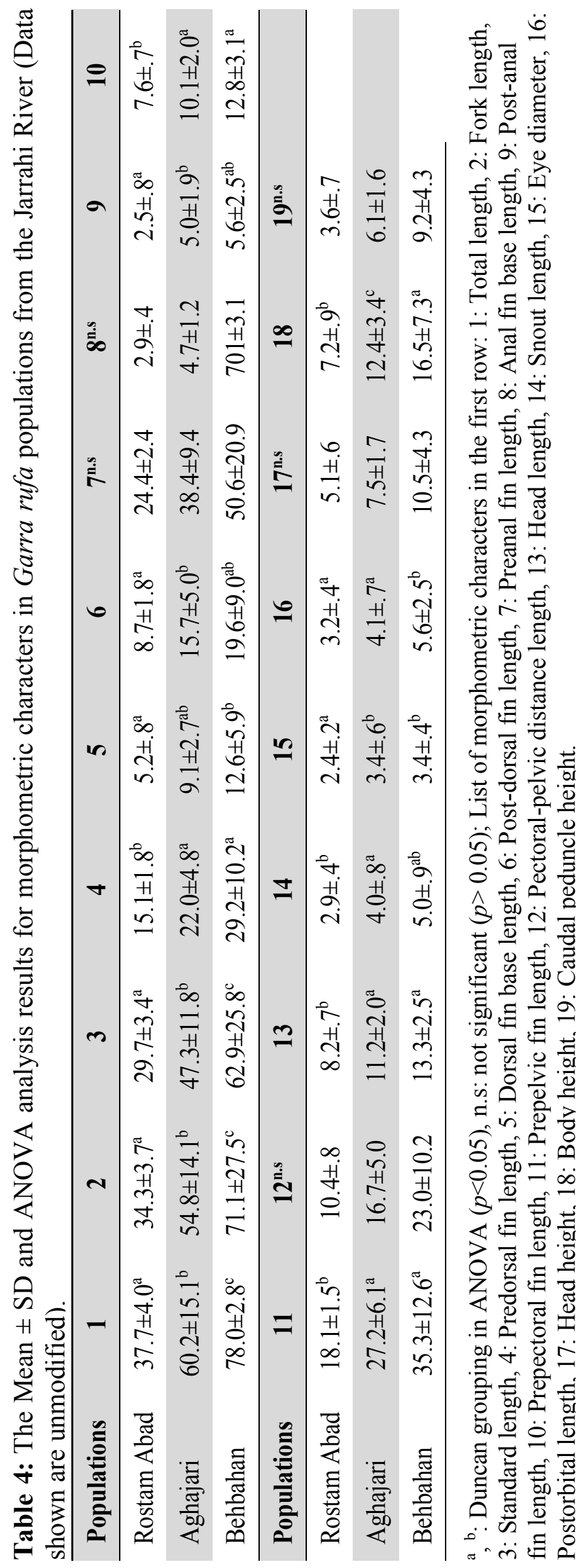




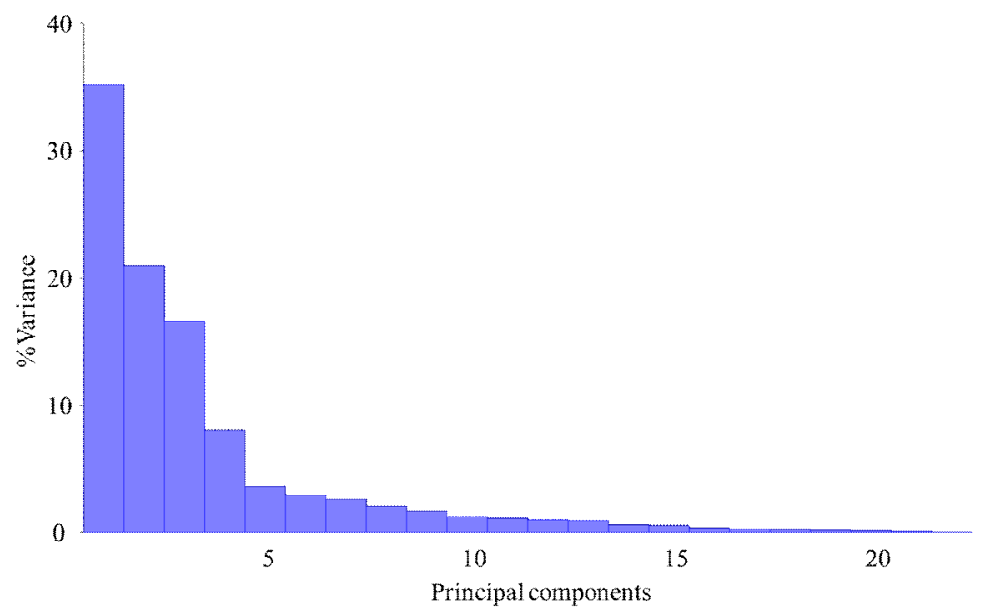

Figure 4: The percentages of total variance for principal components in Garra rufa populations from the Jarrahi River.

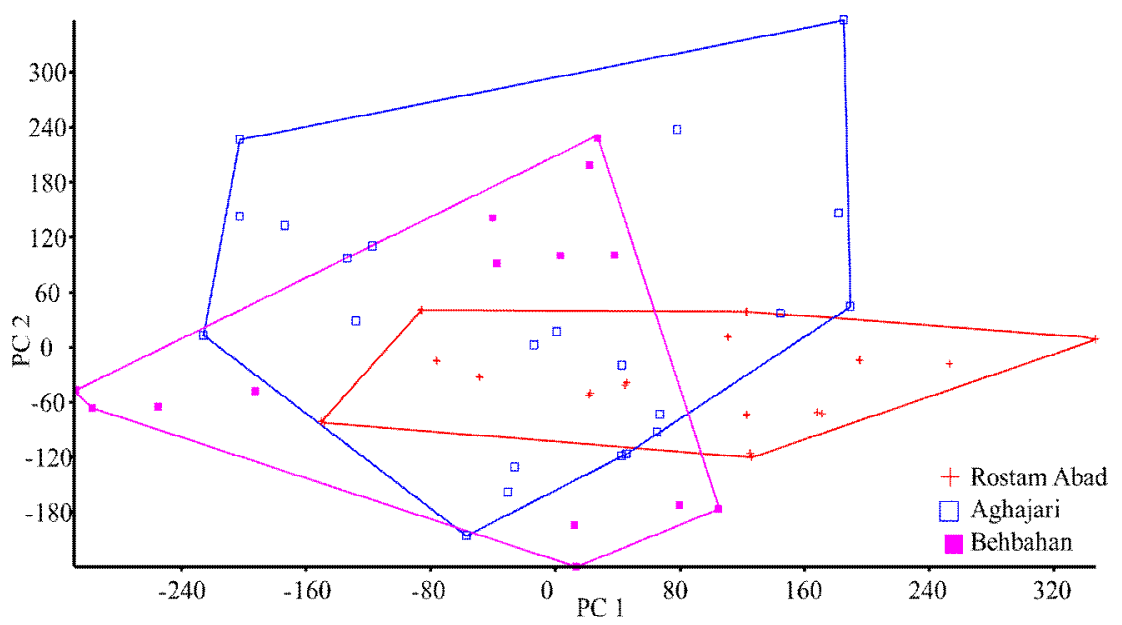

Figure 5: Scatter plots of Principal Component Analysis (PCA) results for Garra rufa in the Jarrahi River.

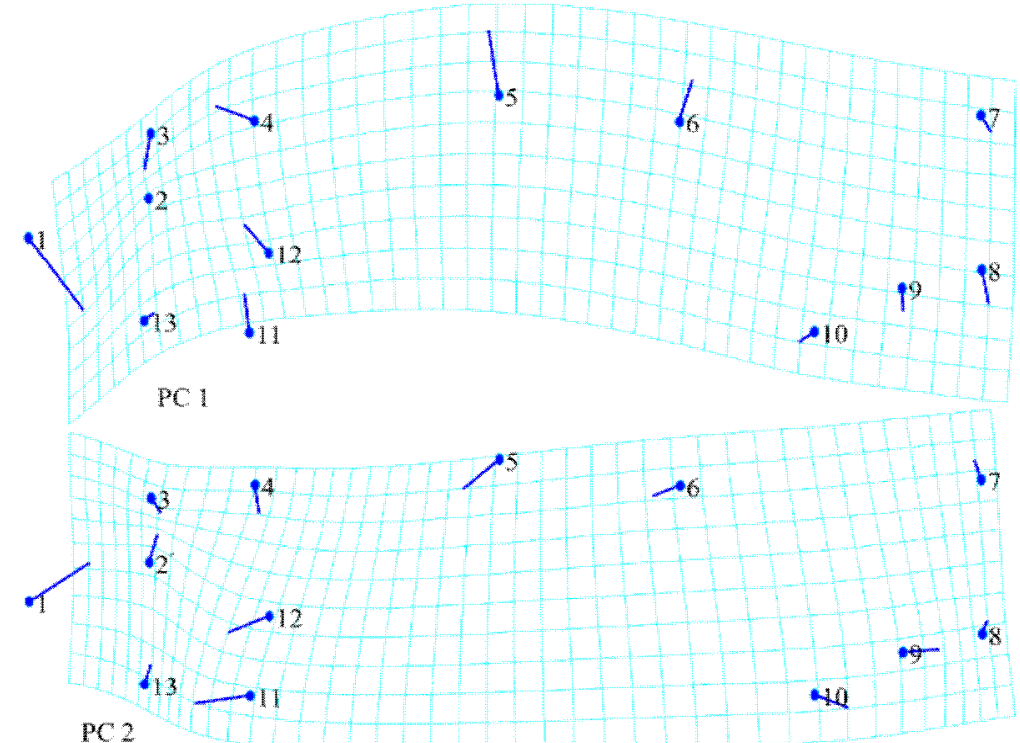

Figure 6: Visualized thin-plate spline transformation grids of Garra rufa body shape rather than the consensus body shape through PC 1 and PC 2 in the Jarrahi River. 
In order to assess small population differences in the shape, CVA was performed between groups. Based on Figure 7, the populations are strongly grouped along the first two axes (CV 1 and 2) and these three populations were different in body shape (Wilks lambda $=0.02532$ and p-value $=0.00000005275$ ) (Fig. 7). Morphological differences between the three population samples were visualized through thin-plate spline transformation grids and photographic representations using canonical axis values from the MANCOVA.

Shape deformation along CV 1 is mostly found on the head region and the beginning and end of the dorsal fin and along CV 2 it is mostly found on the head region, the beginning and end of the dorsal fin and the beginning and end of the anal fin. The Behbahan tributary samples had bigger heads (change in position of landmarks 1, 3, 4, 12 and 13), shorter dorsal fin base lengths (change in position of landmarks 5 and 6), shorter anal fin base lengths (change in position of landmarks 9 and 10) and more shallow caudal peduncles (change in position of landmark 9) than the Rostam Abad tributary samples (Fig. 8).

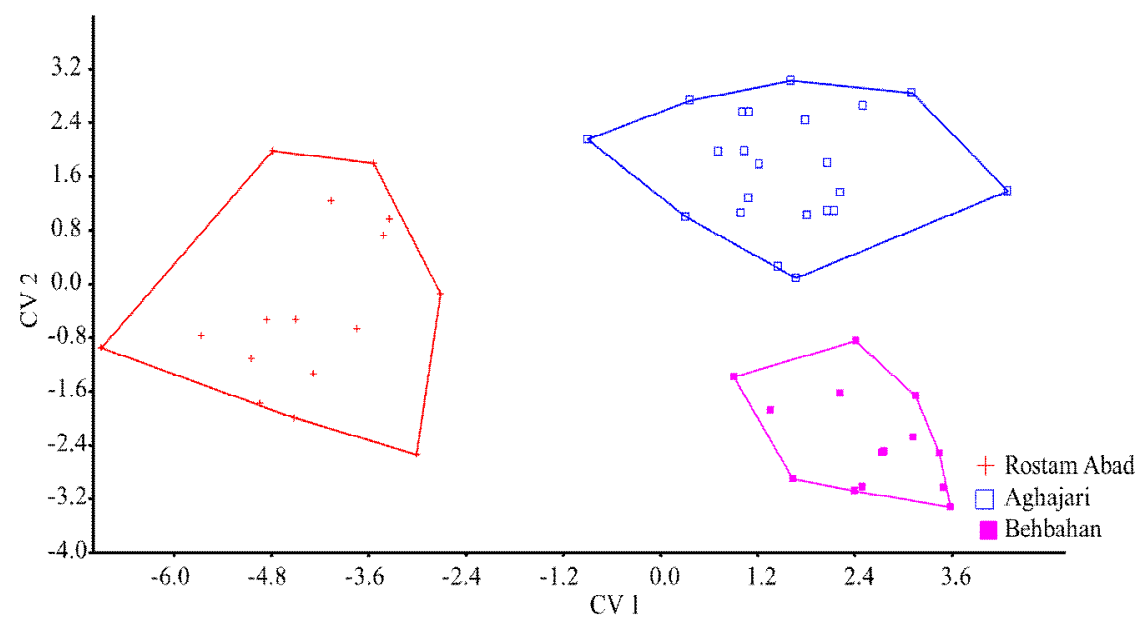

Figure 7: Scatter plots of Canonical Variance Analysis (CVA) result of the studied populations of Garra rufa in the Jarrahi River.

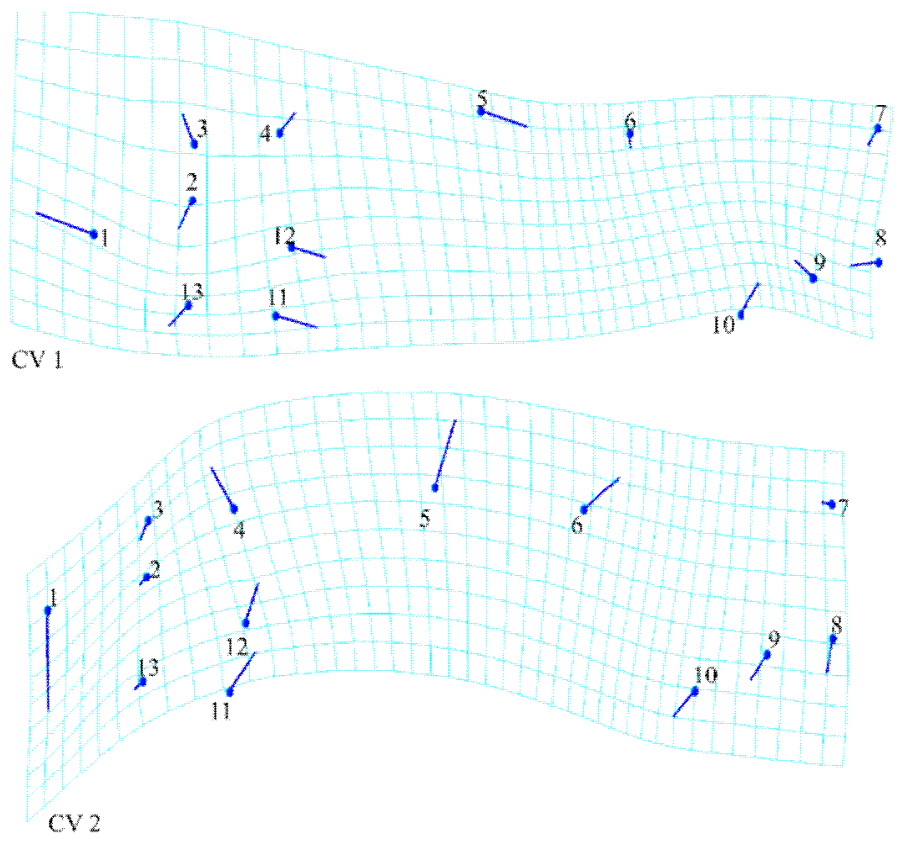

Figure 8: Visualized thin-plate spline transformation grids of Garra rufa rather than consensus body shape through CV 1 and CV 2 in the Jarrahi River. 
The Mahalanobis distances and Procrustes distances results (Table 5) show that there are differences between the body shape of specimens from the Rostam Abad tributary compared to Aghajari and Behbahan tributaries, and the differences were significant $(p<0.0001)$. Most differences were between specimens from the Behbahan tributary and the Rostam Abad tributary.

The Results in Figure 9 show that the populations of Aghajari and Behbahan tributaries were grouped and that the Rostam Abad population was different from the other two populations.

Table 5: Results of Mahalanobis and Procrustes distances from CVA/MANOVA of Garra rufa populations from the Jarrahi River.

\begin{tabular}{ccccccc}
\cline { 5 - 6 } \cline { 5 - 6 } Populations & Rostam Abad & Aghajari & & \multicolumn{3}{c}{ Procrustes distances } \\
\cline { 1 - 2 } Aghajari & 3.78 & & & Aghajari & 0.043 & \\
Behbahan & 4.54 & 2.81 & & Behbahan & 0.051 & 0.035 \\
\hline
\end{tabular}

Distance

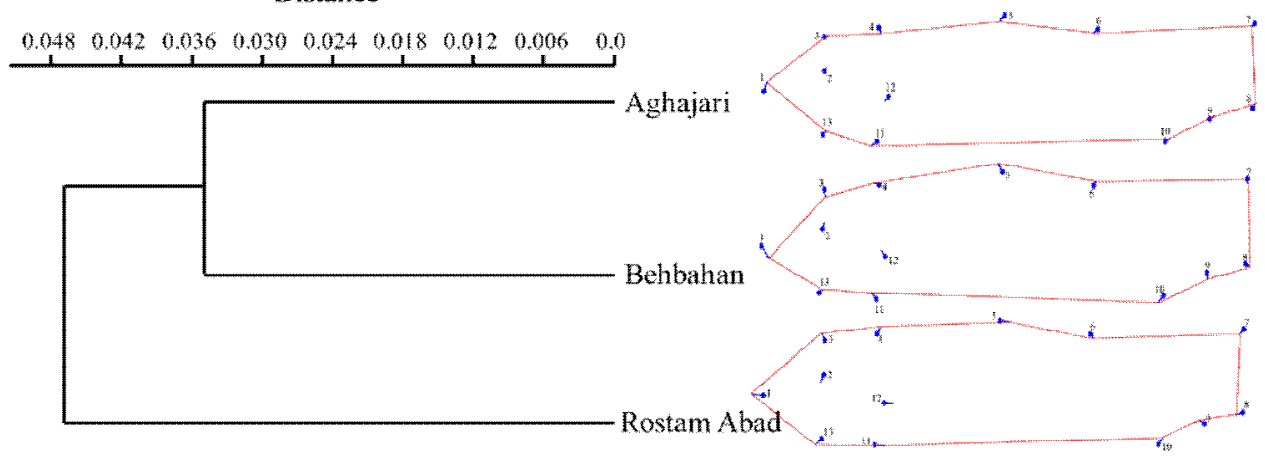

Figure 9: Distance tree of the Cluster Analyses of the three sampled populations of Garra rufa in the Jarrahi River.

\section{Discussion}

The traditional and geometric (landmark-based) morphometric data of Garra rufa specimens used in this study led to the identification of different morphological types. Many fish species exhibit morphological differences between habitats (Schluter and McPhail, 1992). The results of this study show that there were differences between the studied populations in some traditional morphometric traits including meristic characters (number of lateral line scales, predorsal scales and circamucaudal scales), morphometric characters (total length, fork length, standard length, predorsal fin length, dorsal fin base length, post dorsal fin length, post anal fin length, prepectoral fin length, prepelvic fin length, head length, snout length, eye diameter, postorbital length, body height) and in results of the geometric morphometric analysis. The three populations show differences between them and two populations, the Aghajari and Behbahan sites, group together while the Rostam Abad tributary population is separate.

Divergent selection for fish inhabiting different habitats might arise from two major differences between these environments: (1) water velocity and (2) resource availability/composition (Langerhans et al., 2003). All morphological variations between fish populations may be affected by the genetic makeup of individuals, but they may also reflect a series of adaptations to a mixture of environmental factors like temperature, salinity, 
dissolved oxygen, radiation, water depth, current flow influence, food availability, feeding mode and habitat use (Antonucci et al., 2009; Fischer-Rosseau et al., 2009; Spoljaric and Reimchen, 2011). For example, the Rostam Abad site had more vegetation cover, and more electrical conductivity (EC) and total dissolved solids (TDS) than the other sites, but the Aghajari station had more water depth and velocity than other sites. But any discussion about the relationship between body shape and habitat characters needs more detailed measurements of habitat characters and the appropriate analysis to find these relationships.

The CVA result shows that the distinction between the Rostam Abad and Aghajari, Rostam Abad and Behbahan, and Aghajari and Behbahan tributary populations is comparable using Mahalanobis and Procrustes distances showing morphological similarities. In fact, one of the valid ways to statistically evaluate the morphological differences between groups is the use of Mahalanobis and Procrustes distances; although there is a higher Mahalanobis distance between the Behbahan and Rostam Abad populations than between the Behbahan and Aghajari or Rostam Abad and Aghajari tributary populations.

The phenotype of an organisms is always interacting with environmental and biological factors that directly or indirectly affect the body shape and with selection the favorable traits in an environment, increases the chance of survival and reproduction. This can drive the formation of a new population and sometimes even speciation (Spoljaric and Reimchen, 2007).

Five important morphological measurements in ecology and morphology (Ecomorphology) studies of cyprinid species are the position of the dorsal and anal fins relative to the body, the position of the mouth, and the position of the dorsal and anal fins relative to one another (Wood and Bain, 1995). Fish morphology has been linked to habitat use (Videler and Wardle, 1991) and body shape can indicate performance of important tasks such as swimming (Triantafyllou et al., 2000) and feeding (Nilsson and Broenmark, 2000). Body shape may also limit habitat use through biological energy (bioenergetics) constraints. Different habitat types become more costly to use because of design limitations (Facey and Grossman, 1990). Overall, morphology provides physical and biological energy thresholds that contribute to habitat selection and a mechanistic understanding of morphology-habitat associations may be used to identify habitat preferences of a species (Schoener, 1986).

Traditional morphometric and geometric morphometric analysis have many benefits; including they are inexpensive, all the software used is available as freeware, the techniques are faster and easier than molecular techniques, and also are suitable for amateurs (Grinang et al., 2019).

Cicek et al. (2016) studied two species of Garra (G. variabilis (Heckel) and G. rufa) from the Tigris Basin, Turkey, using geometric morphometric methods and their results showed that there is no difference between these two species in terms of size (centroid size); however, they are quite different from each other in terms of shape; and this difference is significant. Cicek et al. (2016) suggested that these differences are thought to be caused by feeding habits and habitat structure.

Keivany et al. (2015a) studied 29 populations of $G$. rufa from six river systems and basins in Iran. They measured 28 morphometric characters and counted 10 meristic characters. Among morphometric traits, the ratio of the dorsal fin base/standard length and pectoral fin/standard length, showed significant differences $(p<0.05)$ and among the meristic traits, except for the number of vertebrae, caudal fin rays and pharyngeal teeth, all other traits were significantly different $(p<0.05)$. Furthermore, thirteen populations of $G$. rufa from the Tigris and Persian Gulf basins in Iran show significant differences in 28 morphometric and nine meristic characters $(p<0.05)$ (Ghalenoei et al., 2010). 
The effects of environmental conditions are predominant during the early stages of fish life and individuals are more sensitive to changes in environmental conditions then (Langerhans et al., 2003). Typically, fish that experience the same environmental conditions in their early life history have the same body shape (Pinheiro et al., 2005). On the other hand, when the fish experience new environmental conditions, it is possible for rapid morphological changes to occur (Poulet et al., 2004).

Recent research has shown that morphological differences between different populations of the same species can be due to genetic separation and also due to environmental differences (temperature, turbidity, food availability, water depth and flow) (Turan, 2000) or contributions from all these mechanisms (Brinsmead and Fox, 2002). To determine the effects of environmental factors, there is a need to study relationships between ecological parameters and morphological traits and to determine the contribution of genetics in differentiation of the morphology. More studies based on the relationship between molecular characters and body shape are also required.

\section{Acknowledgments}

We are pleased to thank Mohammad Asghari and Hadi Khoshnamvand for helping with fish collection. This research was financially supported by Isfahan University of Technology. We appreciate the anonymous reviewers for their careful reading of our manuscript and their valuable comments and suggestions.

\section{References}

Abedi, M., Shiva, A. H., Mohammadi, H. and Malekpour, R. (2011). Reproductive biology and age determination of Garra rufa Heckel, 1843 (Actinopterygii: Cyprinidae) in central Iran. Turkish Journal of Zoology, 35 (3): 317-323. https://doi.org/10.3906/zoo0810-11

Antonucci, F., Costa, C., Aguzzi, J. and Cataudella, S. (2009). Ecomorphology of morphofunctional relationships in the family of Sparidae: A quantitative statistic approach. Journal of Morphology, 270 (7): 843-855. https://doi.org/10.1002/jmor.10725

Bakhoum, S. A. (1994). Comparative study on length-weight relationship and condition factor of the genus Oreochromis in polluted and non-polluted parts of Lake Mariut, Egypt. Bulletin of the National Institute of Oceanography and Fisheries, 20 (1): 201-210.

Brinsmead, J. and Fox, M. G. (2002). Morphological variation between lake- and streamdwelling rock bass and pumpkinseed populations. Journal of Fish Biology, 61 (6): 16191638. https://doi.org/10.1111/j.1095-8649.2002.tb02502.x

Cicek, T., Kaya, A., Bilici, S. and Ünlu, E. (2016). Size and shape analysis of two close Cyprinidae species (Garra variabilis-Garra rufa) by geometric morphometric methods. Journal of Survey in Fisheries Sciences, 2 (2): 35-44. https://doi.org/10.18331 /SFS2016.2.2.3

Costa, C. and Cataudella, S. (2007). Relationship between shape and trophic ecology of selected species of Sparids of the Caprolace coastal lagoon (Central Tyrrhenian Sea). Environmental Biology of Fishes, 78: 115-123. https://doi.org/10.1007/s10641-006-90819

Esmaeili, H. R. and Ebrahimi, M. (2006). Length-weight relationships of some freshwater fishes of Iran. Journal of Applied Ichthyology, 22 (4): 328-329. https://doi.org/10.1111 jj.1439-0426.2006.00653.x 
Esmaeili, H. R., Sayyadzadeh, G., Coad, B. W. and Eagderi, S. (2016). Review of the genus Garra Hamilton, 1822 in Iran with description of a new species: a morpho-molecular approach (Teleostei: Cyprinidae). Iranian Journal of Ichthyology, 3 (2): 82-121.

Esmaeili, H. R., Sayyadzadeh, G., Eagderi, S. and Abbasi, K. (2018). Checklist of freshwater fishes of Iran. FishTaxa, 3 (3): 1-95.

Facey, D. E. and Grossman, G. D. (1990). The metabolic cost of maintaining position for four North American stream fishes: effects of season and velocity. Physiological Zoology, 63 (4): 757-776. https://doi.org/10.1086/physzool.63.4.30158175

Fischer-Rousseau, L., Cloutier, R. and Zelditch, M. L. (2009). Morphological integration and developmental progress during fish ontogeny in two contrasting habitats. Evolution and Development, 11 (6): 740-753. https://doi.org/10.1111/j.1525-142X.2009.00381.x

Fricke, R., Eschmeyer, W. N. and van der Laan, R. (2019). (Eds). Catalog of Fishes: Genera, Species. ${ }^{\circ}$ (http://researcharchive.calacademy.org/research/ichthyology/catalog/fishcatmai n.asp). Electronic version. Accessed 24 December 2019.

Gamelin, F., Baquet, G., Berthoin, S., Thevenet, D., Nourry, C., Nottin, S. and Bosquet, L. (2009). Effect of high intensity intermittent training on heart rate variability in prepubescent children. European Journal of Applied Physiology, 105: 731-738. https://doi.org/10.1007/s00421-008-0955-8

Gerami, M. H., Abdollahi, D. and Patimar, R. (2013). Length-weight, length-length relationship and condition factor of Garra rufa in Cholvar River of Iran. World Journal of Fish and Marine Sciences, 5 (4): 358-361.

Ghalenoei, M., Pazooki, J., Abdoli, A., Hassanzadeh Kiabi, B. and Golzarian, K. (2010). Morphometric and meristic study of Garra rufa populations in Tigris and Persian Gulf basins. Iranian Scientific Fisheries Journal, 19 (3): 107-118. [in Persian]

Gorshkova, G., Gorshkov, S., Abu-Ras, A. and Golani, D. (2012). Karyotypes of Garra rufa and G. ghorensis (Pisces, Cyprinidae) inhabiting the inland water systems of the Jordan basin. Italian Journal of Zoology, 79 (1): 9-12. https://doi.org/10.1080/11250003.2011. 600338

Grinang, J., Das, I. and Ng, P. K. L. (2019). Geometric morphometric analysis in female freshwater crabs of Sarawak (Borneo) permits addressing taxonomy-related problems. PeerJ, 7: e6205. https://doi.org/10.7717/peerj.6205

Hamidan, N. and Britton, J. R. (2013). Length-weight relationships for three fish species (Capoeta damascina, Garra rufa and Nemacheilus insignis) native to the Mujib Basin, Jordan. Journal of Applied Ichthyology, 29 (2): 480-481. https://doi.org/10.1111/jai. 12120

Hammer, Ø., Harper, D. A. T. and Ryan, P. D. (2001). PAST: paleontological statistics software package for education and data analysis. Palaeontologia Electronica, 4 (1): 1-9.

Hashemzadeh Segherloo, I., Tabatabaei, S. N., Mansouri, A., Abdoli, A., Ghalenoei, M. and Golzarianpour, K. (2015). Length-weight relationships of Garra rufa, in the Tigris and Persian Gulf basins of Iran. International Journal of Aquatic Biology, 3 (1): 25-27.

Heistinger, K., Heistinger, H., Lussy, H. and Nowotny, N. (2011). Analysis of potential microbiological risks in ichthyotherapy using kangal fish (Garra rufa). Egyptian Journal of Aquatic Biology and Fisheries, 15 (3): 100-105.

Keivany, Y. and Zamani-Faradonbe, M. (2017). Length-weight and length-length relationships for six fish species from Zohreh River, Iran. International Journal of Aquatic Biology, 4 (6): 387-390. 
Keivany, Y., Nezamoleslami, A. and Dorafshan, S. (2015a). Morphological diversity of Garra rufa (Heckel, 1843) populations in Iran. Iranian Journal of Ichthyology, 2 (3): 148-154.

Keivany, Y., Nezamoleslami, A., Dorafshan, S. and Eagderi, S. (2015b). Length-weight and length-length relationships in populations of Garra rufa from different rivers and basins of Iran. International Journal of Aquatic Biology, 3 (6): 409-413.

Klingenberg, C. P. (2011). Morpho J: an integrated software package for geometric morphometrics. Molecular Ecology Resources, 11 (2): 353-357. http://dx.doi.org /10.1111/j.1755-0998.2010.02924.x

Kottelat, M. and Freyhof, J. (2007). Handbook of European freshwater fishes. Kottelat, Cornol, Switzerland and Freyhof, Berlin, Germany. xiii $+646 \mathrm{pp}$.

Kuliev, Z. M. (1988). Morphometric and ecological characteristics of Caspian Vimba, Vimba vimba persa. Journal of Ichthyology, 28 (1): 29-37.

Langerhans, R. B., Layman, C. A., Langerhans, A. K. and DeWitt, T. J. (2003). Habitatassociated morphological divergence in two Neotropical fish species. Biological Journal of the Linnean Society, 80 (4): 689-698. https://doi.org/10.1111/j.1095-8312.2003. 00266.x

Majtán, J., Černy, J., Ofúkaná, A., Takáč, P. and Kozánek, M. (2012). Mortality of therapeutic fish Garra rufa caused by Aeromonas sobria. Asian Pacific Journal of Tropical Biomedicine, 2 (2): 85-87. https://doi.org/10.1016/S2221-1691(11)60197-4

Mousavi-Sabet, H., Saemi-Komsari, M., Doadrio, I. and Freyhof, J. (2019). Garra roseae, a new species from the Makran region in southern Iran (Teleostei: Cyprinidae). Zootaxa, 4671 (2): 223-239. http://dx.doi.org/10.11646/zootaxa.4671.2.3

Nacua, S. S., Dorado, E. L., Torres, A. J. V. and Demayo, C. G. (2010). Body shape variation between two populations of the white goby, Glossogobius giuris (Hamilton and Buchanan). Research Journal of Fisheries and Hydrobiology, 5 (1): 44-51.

Nicieza, A. G. (1995). Morphological variation between geographically disjunct populations of Atlantic salmon: the effects of ontogeny and habitat shift. Functional Ecology, 9 (3): 448-456. https://doi.org/10.2307/2390008

Nilsson, P. A. and Brönmark, C. (2000). Prey vulnerability to a gape-size limited predator: behavioural and morphological impacts on northern pike piscivory. Oikos, 88 (3): 539546. https://doi.org/10.1034/j.1600-0706.2000.880310.x

Pinheiro, A., Teixeira, C. M., Rego, A. L., Marques, J. F. and Cabral, H. N. (2005). Genetic and morphological variation of Solea lascaris (Risso, 1810) along the Portuguese coast. Fisheries Research, 73 (1-2): 67-78. https://doi.org/10.1016/j.fishres.2005.01.004

Poulet, N., Berrebi, P., Crivelli, A. J., Lek, S. and Argillier, C. (2004). Genetic and morphometric variations in the pikeperch (Sander lucioperca L.) of a fragmented delta. Archiv für Hydrobiologie, 159 (4): 531-554. https://doi.org/10.1127/0003-9136/2004 /0159-0531

Rohlf, F. J. (2010). TpsDig2-Thin Plate Spline Digitise. 2.16 ed. New York: State University of New York.

Rohlf, F. J. and Bookstein, F. L. (1990). Proceedings of the Michigan Morphometrics Workshop. Special Publication 2. The University of Michigan Museum of Zoology. 396 pp.

Schluter, D. and McPhail, J. D. (1992). Ecological Character Displacement and Speciation in Sticklebacks. The American Naturalist, 140 (1): 85-108. https://doi.org/10.1086/285404 
Schoener, T. W. (1986). Mechanistic approaches to community ecology: a new reductionism? American Zoologist, 26 (1): 81-106.

Spoljaric, M. A. and Reimchen, T. E. (2011). Habitat-specific trends in ontogeny of body shape in stickleback from coastal archipelago: Potential for rapid shifts in colonizing populations. Journal of Morphology, 272 (5): 590-597. https://doi.org/10.1002 /jmor.10939

Spoljaric, M. and Reimchen, T. E. (2007). 10000 years later: evolution of body shape in Haida Gwaii three-spined stickleback. Journal of Fish Biology, 70 (5): 1484-1503. https://doi.org/10.1111/j.1095-8649.2007.01425.x

Triantafyllou, M. S., Triantafyllou, G. S. and Yue, D. K. P. (2000). Hydrodynamics of fishlike swimming. Annual Review of Fluid Mechanics, 32: 33-53. https://doi.org/10.1146 /annurev.fluid.32.1.33

Turan, C. (1999). A note on the examination of morphometric differentiation among fish populations: The truss system. Turkish Journal of Zoology, 23 (3): 259-263.

Turan, C. (2000). Otolith shape and meristic analysis of herring (Clupea harengus) in the North-East Atlantic. Archive of Fishery and Marine Research, 48 (3): 283-295.

Videler, J. J. and Wardle, C. S. (1991). Fish swimming stride by stride: speed limits and endurance. Reviews in Fish Biology and Fisheries, 1: 23-40. https://doi.org/10.1007 /BF00042660

Wood, B. M. and Bain, M. B. (1995). Morphology and microhabitat use in stream fish. Canadian Journal of Fisheries and Aquatic Sciences, 52 (7): 1487-1498. https://doi.org /10.1139/f95-143

Wootton, R. J. (1990). Ecology of teleost fishes. Fish and Fisheries Series 1. Chapman and Hall, London. 404 pp.

Yedier, S., Kontaş, S., Bostanc1, D. and Polat, N. (2016). Otolith and scale morphologies of doctor fish (Garra rufa) inhabiting Kangal Balıklı Çermik thermal spring (Sivas, Turkey). Iranian Journal of Fisheries Science, 15 (4): 1593-1608. 